\title{
Luang Prabang: Climate change and rapid development
}

\author{
Matteo Fumagalli \\ School of International Relations \\ University of St Andrews
}

\begin{abstract}
Few other Asian cities have been as orientalised as Luang Prabang, a UNESCO World Heritage site. Situated on the banks of the Mekong River, Luang Prabang has historically been a hub for trade and culture in upland Southeast Asia. The internationalisation engendered by the country's economic reforms and rapid opening up to and integration in regional and transnational economic processes has led to a surge in investment, trade, development assistance and tourist flows. All this has brought opportunities for the residents of Luang Prabang, but such sudden development has also led to socioeconomic dislocation and challenges to both the physical and social fabric of the city. This profile of Luang Prabang looks at the town's geographical location and physical context. This is followed by an account of how spatial use has evolved and the pressures it is under. The article highlights the city's environmental vulnerabilities, zooming in on the impact of climate change which compounds the challenges of rapid development. Far from being fixed in timelessness, the town truly lies at the nexus of local and global processes, experiencing and shaping change, and negotiating the tensions between conservation and development.
\end{abstract}

\section{Highlights}

- Luang Prabang's listing as a UNESCO world heritage site has brought enhanced visibility, funding and tourism to the city.

- A surge in international tourists arrivals challenges the town's social and physical fabric.

- Luang Prabang negotiates the tension between development and conservation.

- Climate change compounds the challenges of rapid development.

- Envioronmental vulnerability is enhanced by the government's focus on natural resource exploitation and a focus on large infrastructural projects. 


\section{Introduction}

Luang Prabang is a town in northern Laos (formally, the Lao People's Democratic Republic, LPDR), the name of which often evokes orientalising memories, especially among a Western public. Luang Prabang is a UNESCO World Heritage site, a status it has kept since 1995 in recognition of the 'specific blend of traditional Laotian and French colonial architecture' (UNESCO, 1995, 47). Home to just over 90,000 inhabitants, ${ }^{1}$ it is the fourth-largest urban centre in the country after the capital Vientiane and the cities of Savannakhet and Pakse in the south (Lao Statistic Bureau 2015; see Table 1).

Luang Prabang has an ancient history. Dating back to the ninth century AD, it became the capital of Lan Xang, one of the largest kingdoms of Southeast Asia in 1345. It subsequently become the seat of the French protectorate and, after independence, the capital of the Royal Kingdom of Laos until 1975, when the communist Pathet Lao took control from the French. Luang Prabang is the centre of Buddhist culture in the country. The name, which literally translates into 'the Royal Buddha image' ('Pha Bang'), derives from a large Buddha statue currently kept in the local Royal Museum.

Rapid economic development and a surge in foreign investment, especially from China, Vietnam and South Korea, as well as a spike in international tourism are rapidly transforming the physical and social fabric of the city. This profile of Luang Prabang examines the rapid transformation of a small but ancient town in upland Southeast Asia, which is undergoing significant economic and social change. The article details how, following the economic reforms introduced under the New Economic Mechanism' in 1986 the city has evolved from being a sleepy tourist backwater to a town that epitomises well the multiscalar nature of globalisation and the way this process and other global dynamics such as climate change interact with local and regional dynamics. As it highlights the impact of the inscription in the UNESCO World Heritage sites and the effects of economic development and the tourism surge that followed, the case of Luang Prabang effectively illustrates the tension between conservation and heritage on the one hand and development and change on the other.

The article is structured as follows. First, it looks at the town's geographical location and physical context, zooming in on the impact of climate change and the environmental

\footnotetext{
${ }^{1}$ Accurate census-taking is notoriously difficult in Laos, and agreeing on how to count, who to count, and what counts as an urban or rural dwelling is notoriously contentious (ADB, 2012, 3).
} 
vulnerabilities to which hte town and its inhabitants are exposed. The article subsequently accounts for how the different historical phases have left their mark on the town's physical structure, paying particular attention to the effects of the economic reforms introduced under the 'New Economic Mechanism' which paved the way for the country's economic opening. The article then turns to Luang Prabang's current socio-spatial structure and highlights the current challenges resulting from various multiscalar, transnational, socioeconomic processes, all of which are having a clear impact on the town, as observed during a period of fieldwork in Luang Prabang and the capital Vientiane in April and May 2016. Next, the article highlights developments affecting urban planning and management, including the impact of the recent surge in international tourist arrivals, before turning to how climate change compounds the challenges of rapid development.

\section{Location and physical context}

Laos is located in the mountainous areas of mainland Southeast Asia, bordering China, Myanmar, Cambodia, Thailand, and Vietnam (Map 1). With a population of about 6.5 million and an overall size of 230,000 sq. km.(91,428 sq. miles), Laos is among the smallest countries in the world, by population and size $\left(102^{\text {nd }}\right.$ and $83^{\text {rd }}$, respectively). Predominantly Buddhist (67\% of the population), it is ethnically diverse, as members of the ethnic Lao group only make up about $53 \%$ of the population, with the rest consisting of 28 other ethnic groups (Lao Statistic Bureau 2015). With a GDP per capita of \$2,566 (2018), it is also among the poorest countries in the world, although the government is striving to get the country to graduate from the least developed country (LDC) status by 2020 , according to the government's $8^{\text {th }}$ National SocioEconomic Development Programme 2016-2020 (Government of Laos, 2016).

The city ${ }^{2}$ of Luang Prabang is situated at $19^{\circ} 53^{\prime} \mathrm{N} 102^{\circ} 08^{\prime} \mathrm{E}$ at an altitude of $305 \mathrm{~m} / \mathrm{s}$. It lies on a small isthmus on the Mekong River, at the confluence between the largest Southeast Asian river and its tributary, the Nam Khan (Map 2), encompassing a small peninsula (about one kilometre long and 250 metres wide) and the surrounding areas, encircled by the PhouThao and PhouNang mountain ranges. Although the easternmost part of the peninsula is rather flat,

\footnotetext{
${ }^{2}$ Formally, Luang Prabang was upgraded to city status in 2017 (Vientiane Times, 2017). Defining what counts as a city in Laos (and what does not) is far from straightforward as competing definitions exist. According to the government there are five possible criteria that distinguish an urban village from a rural one, and a locality should meet at least three.
} 
the western part of the town is dominated by a steep 170-m hillock, Mount PhouSi. The old town, a UNESCO World Heritage site (see section 4), is also home to a number of Buddhist temples and pagodas, as well as to a growing number of service-related businesses, with new developments such as a renovated airport terminal building, a new bridge, and new hotels in the adjacent areas east, south and west of the city.

\section{Map 1. Laos}

[about here, 2 columns]

In a country that is the least urbanised and the least densely populated in mainland Southeast Asia, Luang Prabang is the fourth most populous urban centre in Laos (see Table 1 below). It is located in the eponymous province (also among the least densely populated provinces in the country). Urbanisation has grown by an average of $6 \%$ per year from 2005 to 2015 , and about $37 \%$ of the country's population can be considered urban. As Table 1 shows, the Laotian population as a whole has grown in recent decades; Luang Prabang the city has also grown by a third - by $1.9 \%$ at slightly above the country average of $1.4 \%$, with the overall Luang Prabang province growing slightly less $(0.6 \%)$. Of the approximately 90,300 current residents, about two-thirds (just over 66,781 or 73.9\%) are located in urban villages, whereas around 23,523 (26.1\%) live in rural villages. According to recent projections the city's population is forecast to increase to about 101,800 residents in 2020 and 114,400 in 2025 (JICA, 2016, 2-28).

\section{Table 1. Census data}

[about here, 1 column]

Laos is vulnerable to natural hazards because of the combined effects of environmental degradation and climate variability (ADB, 2017a, 2017b; Cook, 2018; Green Climate Fund, 2015, 2019; Mekong River Commission, 2017; The Laotian Times, 2018; Vidal, 2015). Laos has a sub-tropical climate, with hot temperatures (over 40 degrees Celsius) during the dry season from March to May, and a long wet monsoon season from May to mid-October, with average annual precipitation of ca. 1,442mm, with August being the wettest month (average of $295 \mathrm{~mm}$ of precipitation) (Swisscontact, 2016, 8). Mean annual temperatures have increased by $0.1^{\circ}-0.3^{\circ} \mathrm{C}$ per decade between $1951-2000$, with a mean average of $23.5^{\circ} \mathrm{C}$ during $1901-2016$, 
and they are projected to increase by $1.4^{\circ}$ to $4.3^{\circ}$ by 2100 depending on the specific emissions scenario (MICT, 2017).

The country has experienced a number of adverse weather events like violent thunderstorms, floods, droughts, and mudslides (Vidal, 2015). Floods during the monsoon season in August and September 2018 in the northern Phongsaly and Luang Prabang provinces caused several deaths and damage in Luang Prabang City and the neighbouring Nam Bak and Ngeun districts (Radio Free Asia 2018a, 2018b). As discussed in greater detail in section 5, climate change can compound the severity of those events. The vulnerability of Luang Prabang is rendered more acute by the government's decision to make tourism to the city and its surroundings as key economic driver for the country's development and, additionally, a key driver for its support for large infrastructural projects, from dams to railways, bridges and tunnels. A rapid increase in mass tourism especially places strains on urban infrastructure and services, as examined in the following pages. Although the Lao government has proactively taken measures to adapt to and mitigate the effects of climate change, and has adopted a national strategy focused on resilience and mitigation (Government of Lao PDR, 2009), , environmental degradation continues to be a crucial challenge, and one that critically endangers the city, its residents and surroundings.

\section{History and contemporary dynamics}

Luang Prabang (formally, Luangphabang) has an ancient history dating back to over 1,200 years ago. It was then known under the names Muang Swa (Muang Sua) in the $7^{\text {th }}$ century BCE first, and then and Xieng Dong Xieng until the $13^{\text {th }}$ century. ${ }^{3}$ In 1345 the site became the capital of the Lan Xang Hom Khao ('the kingdom of a million elephants'), one of the largest polities in Southeast Asia. As was typical for the Tai polities of the region, political order was structured around semi-independent principalities, or muang (Stuart-Fox, 2008, 1279). When Lan Xang succumbed to internal strife and broke down into three separate units (Luang Prabang/Luangphabang, Vientiane/Vien Chang, and Champasak), Luang Prabang became the capital of the independent eponymous kingdom in 1707, under Siamese control, extending over both sides of the Mekong river and over an area which included the territory of modern-day

\footnotetext{
${ }^{3}$ For a broader historical overview of Laos, including the history of Luang Prabang, see Askew, Logan and Long (2010).
} 
Laos, as well as the territories of today's north-eastern Myanmar, northern Cambodia and north-eastern Thailand (Stuart-Fox, 1995, 113).

Prior to French intervention, much of present-day Laos, including Luang Prabang, was under Siamese suzerainty (Stuart-Fox, 1995, 113). The Lao people were divided after the FrenchSiamese War of 1893 (Bertrand, 2013, 181), which gave the French control of Laotian territory east of the Mekong River (French Laos), but left territories west of it to the Thai (Siamese Laos, the Isan province of Thailand). France took control of most of the territory that forms today's Lao PDR during its expansion in Southeast Asia, annexing part of it as a colony (the central and southern areas including Vientiane) and ruling over the region of Luang Prabang in the north as a protectorate. The north held jurisdiction over a number of semi-independent tributary muang (principalities), whereas France administered the south directly (Stuart-Fox, 1995, 113). In all effects, within its current boundaries, Laos was born out of the ashes of the French colonial empire (Bertrand, 2013, 181). Luang Prabang became one of the five component units of French Indochina, alongside the colony of Cochinchina and the protectorates of Tonkin, Annam and Cambodia (Stuart-Fox, 1995, 111). In practice, the French considered Laos as little more than the western appendix of Vietnam.

After a brief interlude as a Japanese puppet state in 1945 and the proclamation of Free Laos (Lao Issara) by anti-French nationalists, the French regained their dominance in 1946, and the Lao Issara retreated into exile in Thailand (Bertrand, 2013, 181). Laos finally became independent in 1953, and Luang Prabang was declared the capital of the Royal Kingdom of Laos. What followed was the enmeshment into the brutal wars in Indochina including the Laotian civil war (1959-1975), during which Laos acquired the infamous reputation as the 'world's most bombed country'. ${ }^{4}$ The Lao Resistance Front cooperated closely with the Viet Minh, the communist faction in control of North Vietnam. The war had a devastating impact on the country. Over 40,000 people died, and about a third of the population left the country, leading to changes in the social structure of the towns and villages. In 1975 the Pathet Lao abolished the six-centuries-old monarchy and installed the Lao People's Democratic Republic (LPDR). The ruling Lao People's Revolutionary Party (LPRP) introduced a command economy on a rural population, mostly employed in subsistence agriculture. The country was plunged almost immediately into a harsh economic crisis in the

\footnotetext{
${ }^{4}$ On the legacies of the war, see Baird and Le Billon (2012).
} 
late 1970s, only made worse by the Soviet decision to reduce aid to fellow socialist countries in the mid-1980s.

\section{Economic reforms and the opening of Laos: The effects of investment, aid and tourism ${ }^{5}$}

On the occasion of the $4^{\text {th }}$ Party Congress in 1986 Laos suspended collectivisation and began to follow Vietnam's (and China's) path towards economic reform and liberalisation, while retaining firm political control for the ruling Lao Revolutionary People's Party (LRRP) (Bertrand, 2013, 183). The 'New Economic Mechanism' (NEM, or Jin Ta Na Karn Mai in Lao), modelled around Vietnam's 'Doi Moi' economic reforms led to a progressive opening up of the country and its economy.

By so doing, the authorities were trying to achieve three goals: open up the economy, stabilise and improve economic performance and allow market forces to operate (Stuart-Fox,1989). Prices were liberalised, a new law on foreign direct investment and reforms of the agricultural sector were passed. What followed was a rapid process of progressive industrialisation, rapid economic growth, and urbanisation. Laos opened up to foreign investment and began to receive sizeable amounts of development assistance from a wide range of countries, including Japan, South Korea and Thailand as well as China and Vietnam, which were also important commercial partners and sources of foreign investment.

Economic reforms allowed the regime and the ruling elite to retain both political and economic control, and no alternative power centres have emerged that could challenge the predominance of the LPRP (Bertrand, 2013, 180).

Over the following three decades, Laos has sustained accelerated levels of economic growth, albeit admittedly starting from very low levels. The economy has grown at an average of $6.5 \%$ between 1986 and 2015, and risen further to $6.8 \%$ in 2016 and $6.9 \%$ in 2017 , fuelled by high commodity prices and the export of natural resources, before slowing down to $6.5 \%$ in 2018 , also as a result of the fallout of that year's extensive summer floods and slower hydropower generation (ADB, 2019, 277). Per capita income has grown from $\$ 170$ in 1986 to $\$ 1,127$ in 2010 to $\$ 2,566$ in 2018 (ADB, 2017a, 2017b, 2019). Poverty levels have fallen from $46 \%$ in 1992 to $23 \%$ in 2012. A strong focus on econom growth has overshadowed persisting issues at both macro-economic (large fiscal deficits and a public debt currently at $65 \%$ of the GDP) and

\footnotetext{
${ }^{5}$ Laos tends to be glossed over in scholarly overviews of the region. Barring few notable exceptions (Fau et al., 2014), there is little detail in handbooks on postcolonial urbanism (Bishop, Philips and Yeo, 2003), handbooks of Southeast Asian politics (Robinson, 2014; Slater, 2010), or even the study of urbanisation in the region (Padawangi, 2019). When Laos features in the discussion, it is, understandably, the capital Vientiane that attracts greater attention (Askew et al., 2010; Rafiqui and Gentile, 2009; Walsh and Southiseng, 2009).
} 
micro-economic levels (income levels remain low, even compared with other South-east Asian countries) (ADB, 2019, 278-279).

Although Laos has long been perceived as a remote and isolated country, relations with the outer world are dense and growing, if selective. The country's closest political partners are Vietnam and China, whereas in the development field South Korea and Japan have played a considerable role as part of their efforts at stepping up presence and influence in the region (Fumagalli, 2017), alongside the Asian Development Bank, the United National Development Program (UNDP), and other Western and non-Western donors. Financial aid has surged from $\$ 33 \mathrm{~m}$ in 1960 to $\$ 413 \mathrm{~m}$ in 2010 and $\$ 475 \mathrm{~m}$ in 2017 (OECD-DAC, 2019). Besides development assistance, trade and foreign investment have grown tremendously in recent decades. FDI grew from a meagre \$2m (0.3\% of Laos's GDP) in 1988 to over \$1.2bn in 2015 (8.7\% of GDP) (ADB, 2017a, 2017c,2017d). Vietnam remains the main source of investment (\$813m in 2017), followed by Malaysia and China. Trade balance has similarly increased exponentially, from $\$ 647 \mathrm{~m}$ in 1997 to $\$ 2,060 \mathrm{~m}$ in 2010 and $\$ 2,463 \mathrm{~m}$ in 2015 (ADB, 2012, $2015,2017 \mathrm{c}, 2017 \mathrm{~d})$. Thailand is the main source of imports ( $\$ 4 \mathrm{bn}, 65 \%$ of total), followed by China (\$1bn, 17\%), Vietnam $(\$ 402 \mathrm{~m}, 6.5 \%)$, and South Korea $(\$ 132 \mathrm{~m}, 2.1 \%)$. The destinations for Laos's exports include China (\$1.3bn, 29\%), Thailand (\$1.8bn, 39\%), and Vietnam (\$538m, 11\%) (Simoes and Hidalgo 2011).

Connectivity is one of the buzzwords of the early $21^{\text {st }}$ century, and Laos lies on many of the transport corridors of the region, including the North-South Economic Corridor and the EastWest Economic Corridor of the GMS, a trade and infrastructure project funded by the Asian Development Bank aimed at fostering sub-regional economic integration (ADB 2012; Tan, 2014; Taillard, 2014). ${ }^{6}$ Laos also fits in China President Xi Jinping's Belt and Road Initiative, which includes the $\$ 7 \mathrm{bn} 414-\mathrm{km}$ Chinese-Laos railway linking Kunming to Vientiane. However, there is controversy due to the clear potential for a debt trap, sparking talks of "neocolonialism' (Gray, 2018; Tani, 2018), given the imbalance between China's loans, which Laos cannot afford to repay, and the low financing capacity of the government in Vientiane (Obe and Kishimoto, 2019; Sugiura, 2019).

Last, but not least, a visible aspect of Laos's greater integration in regional and global economic processes, resulting from and enabled by the surge in foreign investment, is the construction of 'energy megaprojects', such as the dams along the Mekong. This is also the terrain on which

\footnotetext{
${ }^{6}$ Luang Prabang also sits on the central and north-east economic corridors of the Greater Mekong Sub-Region (GMS).
} 
different international partners such as China, South Korea and Vietnam vie for influence. Beyond the role of external players, however, is the willingness of the Laotian government to leverage its natural resource wealth and especially the hydro-electric power generation potential to turn itself into the 'battery of South-East Asia'. I return to the social and environmental impact of such projects in section 5, as some of these projects take place in the northern provinces, including in the near proximity to Luang Prabang.

In sum, the economic liberalisation that started in the mid-1980s has brought about a high degree of internationalisation, which, in turn, has led to rapid development As Rehbein (2011, 280) notes, Lao socialism and capitalism 'have been reconfigured by the contemporary forces of the nation-state, transnational links and global capitalism'. The remainder of the article considers the impact of internationalisation and development on the town's socio-spatial structure and contemporary urban development and management challenges.

\section{Spatial structure and land use}

Luang Prabang is built on a peninsula at the confluence of the Mekong River, which flows from the west, and its tributary Nam Kang, which flows from the east before making a sharp turn westward.

The peninsula has historically been Luang Prabang's political and religious centre, with its noble residences and religious buildings. In the heart of the small peninsula stands 150-m-high Mount PhouSi. At the two extremes of the peninsula lie the night market (on the west) and the Buddhist temple Wat Xiengthong on the easternmost side (see Map 3). The two most significant historical sites are the Wat Xieng Thong temple, built in the $16^{\text {th }}$ century, and the Haw Kham Royal Palace Museum. Several other pagodas mark the landscape, including Wat Wisunarat, Wat Xieng Muan, Wat Manorom, and Wat That Luang. Beyond ordinary houses, temples and other buildings of historical significance to the peninsula's townscape are being reshaped by the massive spike in tourism over the past few years, with a growing number of service-related businesses, including guesthouses, restaurants, and spas.

\section{Photo 1}

Photo 2

Photo 3

Photo 4 


\section{Photo 5}

[about here, 2 columns]

Luang Prabang's spatial structure follows the tradition of Tai polities, and is built around a muang and ban structure (Stuart-Fox, 2008). Traditional Lao morphology was heavily influenced by the natural environment and Buddhism. Lao traditional architecture comprised vernacular houses on stilts constructed on bamboo and timber (Leong, Takada and Yamaguchi, 2016, 3). Under French colonial rule, urbanisation was altered as town planning was introduced, forming a grid pattern of roads and blocks (Leong, Takada, and Yamaguchi, 2016, 3). This new urban form was smoothly assimilated into the old traditional one. French influence brought first the introduction of masonry materials and then concrete. Beyond the old town on the peninsula is Luang Prabang's new town, which includes both rural districts and new development areas, such as the newly renovated airport terminal building and new population settlements nearby.

\section{UNESCO World Heritage site}

It is impossible to underestimate the practical and symbolic significance and the impact of the listing of the town of Luang Prabang as a World Heritage site by the United Nations Educational, Scientific, and Cultural Organisation in 1995 (UNESCO, 1995). According to the 1995 inscription, Luang Prabang is:

an outstanding example of the fusion of traditional architecture and Lao urban structures with those built by the European colonial authorities in the $19^{\text {th }}$ and $20^{\text {th }}$ centuries. Its unique, remarkably well-preserved townscape illustrates a key stage in the blending of these two distinct cultural traditions (UNESCO, 1995, 47).

Luang Prabang was nominated as a World Heritage site because it met three criteria: 'to exhibit an important interchange of human values, over a span of time or within a cultural area of the world, on developments in architecture or technology, monumental arts, town-planning or landscape design' (criterion no. 2); 'to be an outstanding example of a type of building, architectural, or technological ensemble or landscaper which illustrates (a) significant stages(s) in human history' (criterion no. 4); and 'to be an outstanding example of a traditional human settlement $[\ldots]$ especially when it has become vulnerable under the impact of irreversible change' (criterion no. 5) (UNESCO, 1995, 47). The inscribed area of 708.53 ha encompasses 
29 (urban) villages, 611 inventory buildings ${ }^{7}, 183$ protected wetlands and, since 2012, a wider buffer zone in the context of the revisions made to the urban plan that year (Leong, Takada, Yamaguchi, 2016, 3). The heritage site was divided into four zones (Leong, Takada, Yamaguchi, 2016, 4):

- ZPP-UA (67.12ha) : core heritage area with a high concentration of historical buildings;

- ZPP-Ub (151.32ha): peripheral area;

- ZPP-M (545.66ha): monasteries;

- ZPP-N (16.43ha): nature including Mount PhouSi, the river banks, the wetlands and the natural forest.

\section{Map 2. Luang Prabang UNESCO World Heritage site}

[about here, 2 columns]

\section{Tourism and its effects}

Luang Prabang is Laos's top tourist destination. Although still far from the figures of Cambodia's Siem Reap and Angkor Wat (which receive about $1.3 \mathrm{~m}$ tourists per year), the impact of its UNESCO inscription was none the less momentous (map 3). One of the key changes enabled by the inscription has been the population surge. The number of residents has not changed dramatically, and the modest increase is in line with country-wide trends. Enabled by the country's opening in the 1980s and the listing of Luang Prabang as a UNESCO World Heritage site in 1995, the number of tourists has risen dramatically (tables 2 and 3). Tourist arrivals have grown from 14,400 in 1990 to over a million in 2005, reaching about 4.9 million in 2018, with arrivals expected to exceed 6.9 million by 2025, generating revenues in excess of $\$ 1.2 \mathrm{bn}$ (MICT, 2017, 30). Four issues stand out as regards tourist flows. The first is the changing profile, where backpackers are now outnumbered by organised tours (especially from East Asia) and wealthy middle-aged or more senior tourists from Europe and North America. Related to this is the three-fold rise in visitors from South Korea and China over the 2012-2017 period (MICT, 2017, 8-12). At 88\% visitors from the Asia-Pacific region represent the bulk of the tourists to Laos. Within this group Koreans, Chinese and Vietnamese are visiting in large numbers along with Thais. While Thais continue to be the main group of tourists at over 1.7 million (MICT, 2017, p. 8-12). The third aspect is the seasonability, as most tourists tend to

\footnotetext{
${ }^{7}$ Invetory buildings are 'significant heritage-listed buildings' (Leong, Takada and Yamaguchi, 2016, p. 3). Some buildings are classified as 'inventory PSMV' and othertrs as 'inventory UNESCO'.
} 
visit after the end of the monsoon season and before the the rise in temperatures, so between November and March. Lastly, which is a limitation to Luang Prabang's appeal, is that tourists tend to follow a similar flow in terms of what attractions they visit, from the temples to the night market, the national museum and then the KuangSi waterfalls and the PakOu caves (MICT, 2017, p. 23).

As Table 2 below shows, which the city's population is expected to grow gradually, the surge in tourist arrivals raises serious questions about their impact on Luang Prabang's social and physical fabric. The dramatic growth in tourist arrivals has resulted in the 'rapid and largely unplanned expansion of transport infrastructure and accommodation facilities' (Swisscontact, 2016). This has added stress on the city's public utilities, water, sewage, garbage collection and the affordability of living by local residents (Swisscontact, 2016, 14).

Table 2. Growing population and tourist flows (2015-2025)

[about here]

Figure 2. Tourist flows and revenues

[about here]

Luang Prabang's role as a major tourist attraction led to rapid construction using inappropriate building techniques, over-densification of buildings, excessive concentration of tourism and tourist businesses, loss of Lao traditional houses, and migration of local residents to outside of the heritage site. In their insightful and detailed in-depth analysis of Luang Prabang between 1999 and 2009, Leong, Takada and Yamaguchi (2016) report similar changes, especially the shift in the usage of buildings and the construction materials. Specifically, the authors identify four main changes: 'a shift from residential to touristic use; the expansion of Lao traditional architecture at the expense of modern architecture; modern building materials are replacing traditional ones; and traditional roof materials are replacing modern roof materials' (Leong Takada and Yamaguchi, 2016, 1). Among the most noticeable changes has been that in the usage of the buildings. If in 2011279 buildings were used in the hospitality sector, the number had gone up to 313 in 2017, with 53 hotels and 260 guest-houses (MICT, 2017, 26).

What is evident is that despite UNESCO's approach towards conservation and a rather static approach to culture and cultural heritage, 'the urban landscape is undergoing tremendous challenges in a short period of time' (Leong et al., 2016), and Luang Prabang's story is that of 'an evolving town' (Dearborn and Stallmeyer, 2009) whose UNESCO designation contributed 
to accelerate the local, regional, and global processes already at play rather than fixing it, spatially or temporally (Berliner, 2012). Luang Prabang lives are shaped by and shape the tension between heritage and conservation, on the one hand, and urban development and growth, on the other. ${ }^{8}$

The spike in tourist arrivals and the infrastructural developments role of the government's economic strategy have both engendered significant changes in land use, despite the restrictions imposed by the city's UNESCO status. To the east of the old town the airport's terminal building has been expanded and upgraded and the runway re-oriented in 2012. Luang Prabang's international airport can now accommodate larger aircraft (Boeing 737 and Airbus 320 ), large enough to sustain the growing traffic connected to the expansion of tourism and now sees about 3,129 inbound and 3,129 outbound flights a year (MICT, 2017). Although traffic remains relatively low, congestion is starting to occur around the new Nam Khan bridge. (JICA, 2016, 2-15). Other problems include the lack of parking space in the heritage area, which means that most parking is concentrated along the river banks, and the pressure on the combined drainage and sewage system, which is often clogged due to waste dumping (JICA, 2016, 2-33).

\section{Urban management and planning: The challenge of managing conservation and development in a UNESCO World Heritage site}

The Laotian government has established an administrative hierarchy of urban areas (ADB, 2012, 3). Beyond the capital Vientiane, there are 16 provincial capitals. Luang Prabang is one of them, as it is home of the Luang Prabang province and 106 district towns. By the mid-1990s, four of the provincial cities - Luang Prabang, Pakse, Savannakhet, and Thakek - had grown more than others and were labelled 'secondary towns'. Luang Prabang was recently upgraded to 'city' status in 2017, as the government aimed to fast-track the city's economic development (Vientiane Times, 2017).

Urban development in Laos involves planning and policy-making at various levels, including the central government, provincial and city authorities, and international agencies funding or implementing heritage conservation strategies. Decentralisation began in the 2000s in Laos,

\footnotetext{
${ }^{8}$ For a more detailed discussion of this tension between economic development and heritage conservation, see Dearborn and Stallmeyer (2009), Long and Sweet (2006), Sims (2015a and 2015b), Southiseng and Walsh (2011), Staiff and Bushell (2013), and Vongpraseuth and Choi (2015).
} 
which means that the government in Vientiane progressively deferred both the development of urban planning and management and revenue generation to the local level. Urban Development Administration Authorities (UDAAs) were established in Vientiane and the four other secondary towns between 1997 and 1999 (ADB, 2012, 5). Their initial task was that of managing and implementing ADB-financed urban infrastructure projects (ADB, 2012, 5) 9 . Starting from 2000, as part of the decentralisation process mentioned above, the UDAAs were endowed by the government with the status equivalent to provincial governments, financially independent, and able to generate their own revenues and spend them for urban improvement (ADB, 2012, 5). Despite the best intentions of the government and the Asian Development Bank, UDAAs have been unable to function effectively, given their low capacity and limited staff and resources.

Another issue hindering urban improvement projects was the confusion in the early stages concerning the division of competencies among various institutions and agencies. This issue was especially visible in Luang Prabang. With regard to the planning process of urban plans, responsibilities overlapped between UDAAs and the provincial Department of Public Works and Transport (DPWT). Similarly problematic was the division of responsibilities between spatial and economic planning (ADB, 2012,6), the first undertaken by the DPWT and the latter by the Ministry for Planning and Investment. Urban plans, infrastructure plans, and urban sector strategies fall under the remit of the DPWT, but the two struggled to coordinate. The poor planning and implementation of urban plans were a case in point, given the 'overlapping and unclear responsibilities [...] hindering the planning process' (ADB, 2015, 6). Among the most pressing issues were those of coordination among the various authorities involved in the management and development of urban services in Luang Prabang, where the task of managing urban plans is rendered more complex by the presence of yet another actor. Starting from 1995 a new complex regulatory system was put in place to deal with urban planning of the UNESCO World Heritage Site and the surrounding areas. A new system involving UNESCO, the city of Chinon and the Centre region of France with funding from the French Agency for Development and UNESCO, was put in charge of the protected area in the old town (Boccardi and Logan, 2007, 10). The Heritage House, or Maison du Patrimoine (MdP), is the body that oversees the implementation of the Safeguarding and Enhancing Plan and the 2012 Urban Plan (Leong, Takada and Yamaguchi, 2016, 4). The MdP was established to manage and monitor

\footnotetext{
${ }^{9}$ The Asian Development Bank and JICA have been the main partner for urban improvement projects in several other Southeast Asian cities, like Mandalay in neighbouring Myanmar (Kim, 2018).
} 
developments in the heritage area according to the Plan for Safeguarding and Valorisation (Maison du Patrimoine, 2001a and 2001b). The MdP is also tasked with providing consultations with the locals, approving building permits, and managing conservation and infrastructure projects (Leong, Takada and Yamaguchi, 2016, 4).

What became increasingly evident was that different actors had divergent interests and priorities and different understandings of what the town's needs were. UNESCO and MdP, drawing on the former's rather static understanding of cultural heritage (centred on the notion of tangible heritage and a fixed, 'authentic' culture), advocated conservation and resisted the pressure on building use, particularly in relation to Lao traditional architecture (Leong, Takada and Yamaguchi, 2016; Dearborn and Stallmeyer, 2009). By contrast, local entrepreneurs and Laotian authorities were keen on taking advantage of the opportunities that the country's opening and the town's listing offered, with a far more relaxed approach towards the use of local buildings. Referring to Laos at the turn of the century the United Nations Environment Program noted that 'since the towns are still small, population densities are low, $[\ldots]$ and industrial activity is only emerging in a few of the country's largest towns, the ambient effects of urban activities are minor and localised' (UNEP, 2001). Thus, Laos's towns and cities appeared to have been spared 'the range of problems associated with urbanization in other parts of Asia' (UNEP, 2001). This is clearly no more: 'Laos is [actually] changing at an incredible pace' (Rehbein, 2011, 300). T

UNESCO's listing of Luang Prabang as a World Heritage site was certainly momentous, as it brought notoriety and opportunities, also of an economic nature. Yet, it also amplified the challenges of a small town in a vulnerable environment in a late-developing country. The spike in tourist arrivals and the changing use of many local buildings, compounded with broader changes engendered by economic development, were increasingly at odds with UNESCO and the MdP's priorities related to the conservation of the town's tangible (architectural, primarily) and, increasingly, intangible (cultural) heritage. This has highlighted the contradictions of a society that lives in different times (Rehbein, 2011,300), including one that UNESCO seeks to preserve with its focus on conservation of tangible and intangible heritage and that of globalisation and multiple connectivities of a town's integration into the global economy, promoted by local city and provincial administrators and the central government, keen on making the town 'the pole of the north' in their socio-economic development strategies, and a variety of other international actors, such as the Asian Development Bank.

According to the government's $8^{\text {th }}$ National Socio-Economic Development Plan and the Vision 2030 (Tappe, 2018, 170), the authorities are keen not only to lift Laos out of its LDC status by 
2020, but also to attain middle-income status by 2030. To these ends, al infrastructural development and natural resource exploitation are crucial dimension of the economic strategy. Many of the 'mega-projects' functional to this strategy are the railway connecting China and Laos up to the Thai border (Tappe, 2018, 175-176). Constructing the railway entails building bridges on the Mekong and tunnels through the mountainous areas of northern Laos. In close proximity to the railway line in Luang Prabang would be built another bridge and a commercial port (Gray, 2018) for larger ships.

In sum, the socio-economic changes that have transformed Luang Prabang in recent decades have highlighted the tension between development and conservation needs. Juggling between competing priorities and agendas was rendered even more complicated by the overlapping competencies and somewhat unclear division of competencies identified earlier.

\section{Climate change and urban development: Environmental vulnerability and the challenge of sustainability}

Climate change compounds the challenges of rapid development. The Mekong region is widely acknowledged as among the most vulnerable regions of Southeast Asia due to flash floods and droughts (GCF, 2015, 3; Mekong River Commission, 2017). Extreme weather events have increased in frequency and intensity in recent years.

Although urbanisation has proceeded at a slower pace in Laos compared to its neighbours, it is nonetheless advancing, and the effects of pollution and climate change are beginning to surface (ADB, 2012, 8). The government is trying to tackle this challenge, seeking to make Lao cities 'greener and more liveable and sustainable' (Government of Lao PDR, 2009), and is assisted by a number of international partners, most notably the Asian Development Bank, which supports and funds much of the urban improvement projects, seeking to combine a focus on inclusive growth and transport and trade connectivities with attention to sustainability (ADB, 2012, 2015). The Laotian government has shown early awareness of the threats that climate change and environmental degradation pose to its ecosystems and has sought to take the initiative to adapt and mitigate the effects of climate change. In 1995 the Government of Laos ratified the UN Framework Convention (UNFC) and ratified the UNFC on Climate Change. In 2008, it established the National Steering Committee on Climate Change, and in 2009 it released the National Adaptation Plan of Action. This was followed by the adoption of an Adaptation Strategy in 2010 (Government of Lao PDR, 2009; GCF, 2019). The country's 
eighth NSEDP (2016-2020) (Government of Lao PDR, 2016) makes explicit references to climate change challenges and makes adaptation and mitigation its strategic priorities (NSEDP, 2016, outcome 3). This dovetails with the Asian Development Bank's Country Partnership Strategy for 2017-2020, in which adopting measures to mitigate the effects of climate change is indicated as a strategic priority (ADB, 2017b, 2017c).

A good illustration of the fine line that the Laotian government is walking between development and conservation is the launch of a new dam project in Luang Prabang's Chomphet district, some $23 \mathrm{~km}$ to the west of the city (Kang, 2019). The hydropower project is expected to generate around 1,410 MW, making it the largest such project in the country. This may be crucial to Laos's economic growth and a source of exports, but is a contentious issue at home, where 500 families (ten villages) are expected top be displaced (RFA 2019b) ${ }^{10}$ and abroad, with the neighbouring countries displeased with both the lack of consultation by the government in Vientiane. Far from heralding an era when the country will turn into the battery of Southeast Asia, dams in Laos are proving extremely problematic. The growing number of dams have meant lower water levels on the Mekong, decline in fisheries, loss of sediment and alterations in flow patterns, all affecting the food security and livelihood of communities living in the river basin (Nachemson 2019). The collapse of the South Korea-funded dam in Xe Pian Xe Namony in July 2018, killing over forty people, with thousands being resettled (RFA 2019a). The authorities in Vientiane appear to be unaffected by the environmental concerns raised by various environmental groups.

Laos has been recognised as a country vulnerable to climate variability and disasters (The Laotian Times, 2018), with a low capacity to adapt to climate change due to its low socioeconomic conditions (GCF, 2019). Rainfall during the wet season has increased in recent years, resulting in floods, particularly in the northern provinces. In the dry season, temperatures have become hotter, affecting the planting of crops and the rearing of livestock and fisheries, with shortfalls in agricultural production $(\mathrm{GCF}, 2015,3)$. Natural disasters are far from uncommon in Laos (Figure 2), with 46 natural hazard events recorded from 1970 to 2018, affecting some nine million people overall and causing economic damages in excess of $\$ 400 \mathrm{~m}$ (GCF, 2019; GCF, 2015, 3). Floods are the most frequent type of natural hazard (twenty-six), alongside epidemics (nine), storms (six) and droughts (five).

\footnotetext{
${ }^{10}$ By the time of completion the dam project will have displaced 4,600 people across various districts of the Luang Prabang province (RFA 2019b).
} 
Figure 3. Natural hazards in Laos (1900-2018)

[about here]

Floods and droughts have increased in frequency and severity between 1985 and 2010, with fifteen floods in the 1970-2010 period, five droughts over the past forty years and five storms/tropical cyclones over the past twenty (GCF, 2019). About $70 \%$ of the population depends on natural resources and agriculture for their livelihoods (GCF, 2019). As only 13-14\% of food is grown on irrigated land, drought can have a serious impact on the food security of local residents. Losses from droughts and especially floods, for example, are having an impact on economic growth (an estimate of $2.8-3.6 \%$ of GDP) and government (about 2.7\%; Gending GF, 2015, 2). Deforestation (Laos has lost one-third of its forests in recent decades), the centrality of natural resource development (and export) as a cornerstone of the government's industrial policy, and its emphasis on making the country a 'hydro superpower' through the building of dams have further increased the country's exposure to natural disasters.

The government's plans to turn the country into a major hydropower in the region by building up to 140 dams in the coming years is extremely risky environmentally and has caused significant domestic and international opposition (RFA, 2018b). The country is exposed to climate change threats, including floods, droughts, and water and food insecurity, with an impact on hydrology, ecology, agriculture, fisheries, and hydropower development (GCF, 2015, 3). Conditions are getting worse across a number of parameters and sectors, as identified in the Inter-governmental Panel on Climate Change's assessment of climate change impact on Laos: annual mean temperatures will continue to rise by $0.1-0.3$ degrees Celsius per decade, and the number of days over 33 degrees per year will increase. The number of cooler days (below 15 degrees Celsius) will also decrease; dry seasons will get longer; and there will be more intense rainfalls. Laos and its northern provinces are experiencing this already.

The northern provinces of the country were especially affected by the 2018 monsoons, with heavy rainfall causing extensive flooding in Luang Prabang and the Nam Bak and Ngeun districts, resulting in six deaths, plus casualties and damages, including collapsed bridges and landslides (RFA, 2018a). In its 2020 Vision, the national government has identified Luang Prabang as 'the pole of north', central to its economic development of the northern provinces (ADB, 2017a). The presence of rugged terrain and a tenuous road system - northern Laos's only airport is also in Luang Prabang — has made the improvement of road and infrastructure in and around the city a priority. Growing urbanisation along the economic corridor that 
accompanies such strategies has also meant additional strains on the highly vulnerable ecosystems.

\section{Conclusion}

'A historic city needs both continuity and change', rightly note Leong et al. (2016). Like other cities of the Global South, Luang Prabang's challenge is one of simultaneously managing urban development and conservation and therefore understanding its current challenges, offering the opportunity to shed light on oft-overlooked aspects in the study of cities in the Global South, namely the relationship between urban development and improvement and environmental challenges (Post, 2018). This article has shown that the challenges arising from rapid development are rendered more acute by the multi-scalar politics of regional and trans-national integration such as the Greater Mekong Sub-region's economic corridors and China's Belt and Road Initiative, Luang Prabang needs to 'navigate' an increasingly complex matrix which includes multiple agencies and institutions, often with unclear division of competencies and overlapping mandates, and different agendas and interests, which lead to problems of poor coordination, 'poor urban management, little strategic spatial planning, poor connectivity between urban planning and environmental management, and insufficient investment in infrastructure and community services' (ADB, 2012, 2). Changes are taking place with 'minimal coordination, inadequate infrastructure, and insufficient regard for environmental impacts' (ADB, 2012, 2).

Growth in foreign investment, trade, development assistance, and mass tourism, especially from other East Asian countries such as Vietnam, China, Thailand, and South Korea, is placing additional strains on a vulnerable physical and social fabric. Such challenges are further compounded by climate change. The priority for Luang Prabang, local city and national administrators, and the international community is to make the town's present and future more sustainable; that means more environmentally conscious and sustainable strategies for economic development and active measures aimed at mitigating the effects of climate change. Far from being a 'laidback backwater' or fixed in timelessness, the town truly lies at the nexus of local, regional and global processes and connectivities, while taking active part in shaping them. 


\section{References}

Asian Development Bank (ADB) (2019). Asian Development Outlook 2019. ADB: Manila. ADB (2017a). Lao People's Democratic Republic, 2017-2010: More inclusive and sustainable economic growth. Country Partnership Strategy. ADB: Manila.

ADB (2017b). Fostering competitive cities and urban areas in the Greater Mekong Subregion: Building inclusive economic cluster sustainably. ADB Southeast Asia Working paper series, n. 14, August, ADB: Manila.

ADB (2017c). Lao PDR. Accelerating structural transformation for inclusive growth. Country Diagnostic Study. ADB: Manila. ADB (2017d). Lao People's Democratic Republic. Emerging from least developed country status. Development effectiveness brief. ADB: Manila.

ADB (2015). Proceedings of the Greater Mekong Subregion urban development and planning training program. ADB: Manila.

ADB (2012). Lao People's Democratic Republic. Urban Development Sector Assessment, Strategy and Road Map. ADB: Manila.

Askew, M., Logan, W. S., and Long, C. (2010). Vientiane: Transformations of a Lao landscape. London: Routledge.

Baird, I. G., and Le Billon, P. (2012). Landscape of political memories: War legacies and land negotiations in Laos. Political Geography, 31, 290-300.

Berliner, D. (2012). Multiple nostalgias: The fabric of heritage in Luang Prabang (Lao PDR). Journal of the Royal Anthropological Institute, 18(4), 769-786.

Bertrand, J. (2013). Political change in Southeast Asia. Cambridge: Cambridge University Press, 179-189.

Bishop, R., Philips, J., \& Yeo, W.W. (eds) (2003). Postcolonial urbanisms. Southeast Asian cities and global processes. London: Routledge. Boccardi, G. and W. Logan (2007) Reactive Monitoring Mission to the Town of Luang Prabang World Heritage Project, Lao People's Democratic Republic.

Centre of Excellence in Disaster Management and Humanitarian Assistance (2017). Lao PDR. Disaster management reference handbook. Reference Handbook, Joint Base Pearl Harbour, HI.

Cook, E. (2018). With its environmental crisis, is Laos missing the forest for the trees? The Diplomat, 6 January.

Dearborn, L. M., and Stallmeyer, J. C. (2009). Re-visiting Luang Prabang: Transformations under the influence of world heritage designation. Journal of Tourism and Cultural Change, 
7(4),

Evans, G. (1999). Laos. Culture and Society. Chiang Mai: Silkworm Press.

Fau, N., Khonthapane, S., and Taillard, C. (Eds) (2014). Transnational dynamics in Southeast Asia: The Greater Mekong Subregion and Malacca Straits economic corridors. Singapore: ISEAS.

Gray, D. (2018). Tourism and development threaten Laos' French traditions. Nikkei Asian Review, 1 March.

Fumagalli, M. (2017). South Korea's relations with Myanmar: A stepping stone to enhanced global engagement. Washington, D.C.: Korea Economic Institute of America.

Government of Lao PDR (2009). National adaptation program action. Vientiane.

Government of Lao PDR (2016). $8^{\text {th }}$ Five-year national socio-economic development plan (NSEDP) 2016-2020. Vientiane: Ministry of Planning and Investment.

Green Climate Fund (GCF) (2019). Lao People's Democratic Republic. Country Programme. Vientiane, February.

GCF (2015). Ecosystems and urban adaptation in Lao PDR: Concept note. Incheon: Green Climate Fund.

Ho, S. (2018). Can the China-Laos railway keep on track? East Asia Forum, 12 July. Japan International Cooperation Agency (JICA) (2016). Data Collection Survey on Regional Development in Luang Prabang, Lao PDR. Vientiane: JICA, International Development Center of Japan Inc., Nippon Koei Co. Ltd., November. Kang. T. (2019). Laos to continue Luang Prabang Dam Project. The Laotian Times, 25 September.

Kim, Y. (2018). Mandalay, Myanmar: The remaking of a South-East Asian hub in a country at cities. International Journal of Urban Policy and Planning, 72B, 274-286.

Lao Statistic Bureau (2005). Lao Population Census (2005). Vientiane, Lao PDR. Lao Statistic Bureau (2015). Lao Population and Housing Census (2015): Results of population and housing census 2015. Vientiane, Lao PDR.

Leong, C., Takada, J., Hanaoka, S. and S. Yamaguchi (2017). Impact of tourism growth on the changing landscape of a world heritage site: Case of Luang Prabang, Lao PDR. Sustainability, 9 (11), available at https://doi.org/10.3390/su9111996, 1-12. Leong, C., Takada, J., \& Yamaguchi, S. (2016). Analysis of the changing landscape of a world heritage site: case of Luang Prabang, Lao PDR. Sustainability, 8 (8), available at https://doi.org/10.3390/su8080747, 1-23. 
Long, C., and Sweet, J. (2006). Globalization, nationalism and world heritage: Interpreting Luang Prabang. South East Asia Research, 14(3), 445-469.

Maison du Patrimoine (2001a). Luang Prabang. Règlement. Plan de sauvagarde et de mise en valeur. Sommaire. Luang Prabang. https://www.luangprabang-laos.com/Heritage-House-andUNESCO Accessed 20 January 2019.

Maison du Patrimoine (2001b). Luang Prabang. Rapport de presentation. Plan de sauvagarde et de mise en valeur. Sommaire. Luang Prabang. https://www.luangprabanglaos.com/Heritage-House-and-UNESCO Accessed 20 January 2019.

Mekong River Commission (MRC) (2017). Mekong: Climate change adaptation strategy and action plan. Vientiane.

Ministry of Information, Culture and Tourism (MICT) (2017). 2017 Statistical Report on Tourism in Laos. Vientiane.

Nachemson, A. (2019) Laos to go ahead with Luang Prabang dam project despite warnings. $A$ Jazeera, 24 September.

Obe, M., and Kishimoto, M. (2019). High-speed dreams. Asian Nikkei Review, 14-20 January, 8-14.

OECD-DAC (2019). Development Finance Data. Aid at a Glance. Available at https://public.tableau.com/views/OECDDACAidataglancebyrecipient_new/Recipients?:embe

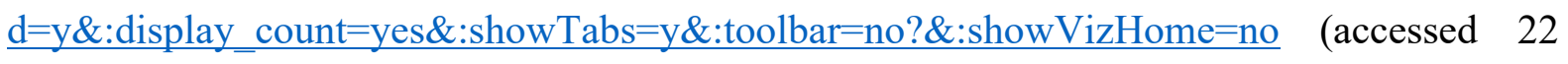
October 2019).

Padawangi, R. (Ed) (2019). Routledge handbook of urbanization in Southeast Asia. London: Routledge.

Pholsena, V. (2006) Postwar Laos. The politics of culture, history and identity. ISEAS: Singapore.

Post, A. E. (2018). Cities and politics in the developing world. Annual Review of Political Science, 21, 115-133.

Radio Free Asia (RFA) (2019a). Nearly 500 families to be displaced this month for Laos' fifth Mekong River Dam. 12 July.

RFA (2019b) Villagers brace for resettlement amid signs Laos wants to build another mainstream Mekong Dam. 19 June.

Radio Free Asia (2018a). Flooding kills at least six people in Laos's Luang Prabang Province, 30 August.

Radio Free Asia (2018b). Death toll rises in floods, landslides in Laos. 6 September. 
Rafiqui, P. S., and Gentile, M. (2009). Vientiane: Cities. International Journal of Urban Policy and Planning, 26, 38-48.

Rehbein, B. (2011). Differentiation of sociocultures, classification, and the good life in Laos.

Sojourn. Journal of Social Issues in Southeast Asia, 26 (2), 277-303.

Robinson, R. (Ed) (2014). Routledge handbook of Southeast Asian politics. London: Routledge.

Sims, K. (2015a). Culture, community-oriented learning and the post-2015 development agenda: a view from Laos. Third World Quarterly, 36(10), 1922-1943.

Sims, K. (2015b). The Asian Development Bank and the production of poverty: Neoliberalism, technocratic modernization and land dispossession in the Greater Mekong Subregion. Singapore Journal of Tropical Geography, 36, 112-126.

Simoes, AJG and Hidalgo, CA (2011). The Economic Complexity Observatory: An Analytical Tool for Understanding the Dynamics of Economic Development. Workshops at the TwentyFifth AAAI Conference on Artificial Intelligence.

Sugiura, E. (2019). Laos can 'manage' debt to China, PM insists. Nikkei Asian Review, 31 May.

Slater, D. (2010). Ordering power: Contentious politics and authoritarian Leviathans in Southeast Asia. Cambridge: Cambridge University Press.

Southiseng, N., \& Walsh, J. C. (2011). Study of tourism and labour in Luang Prabang Province. Journal of Lao Studies, 2(1), 2159-2152.

Staiff, R., \& Bushell, R. (2013). Mobility and modernity in Luang Prabang, Laos: re-thinking heritage and tourism. International Journal of Heritage Studies, 19, 98-113.

Starin, D. (2008). World heritage designation. Critical Asian Studies, 40(4), 639-652.

Stuart-Fox, M. (2008) City planning of the Lao/Thai. In H. Seline (ed) Encyclopedia of the history of science, technology and medicine in non-western cultures. New York: Springer.Stuart-Fox, M. (1995) The French in Laos 1887-1945. Modern Asian Studies, 29(1), 111-139.

Stuart-Fox, M. (1989) Laos in 1988: In pursuit of new directions. Asian Survey, 29(1), 8188.

Swisscontact (2016). Lao PDR Tourism Destination Management Plan 2016-2018. Vientiane. Taillard, C. (2014). Corridors and cities: connectivity or integration processes in Southeast Asia? In N. Fau, S. Khonthapane, \& C. Taillard (Eds), Transnational dynamics in Southeast Asia: The Greater Mekong Subregion and Malacca Straits economic corridors (pp. 455-486). Singapore: ISEAS. 
Tan, D. (2014). Chinese networks, economic and territorial redefinitions in Northern Lao PDR. In N. Fau, S. Khonthapane, \& C. Taillard (Eds), Transnational dynamics in Southeast Asia: The Greater Mekong Subregion and Malacca Straits economic corridors (pp. 421-452). Singapore: ISEAS.

Tani, S. (2018). Laos 'not concerned' about debt from China's Belt and Road. Nikkei Asian Review, 12 June.

Tappe, O. (2018). On the right track? The Lao People's Democratic Republic in 2017. Southeast Asian Affairs, vol. 2018, 169-183.

The Laotian Times (2018). Laos ranked $42^{\text {nd }}$ most vulnerable country to climate change. 10 July. The Guardian, 25 November.

United Nations Educational, Scientific and Cultural Organization (UNESCO) (1995). Convention concerning the protection of the world cultural and natural heritage. World Heritage Committee, $19^{\text {th }}$ session, Berlin, 4-9 December.

United Nations Environment Programme (UNEP). (2001). Lao PDR: State of the Environment 2001. Bangkok: UNEP.

Vidal, J. (2015). Laos counts the cost of climate change: records floods, drought and landslides. The Guardian, 25 November.

Vientiane Times (2017). Luang Prabang upgraded from town to city. 8 November.

Vongpraseuth, T., and Choi, C. G. (2015). Globalization, foreign direct investment and urban growth management: policies and conflicts in Vientiane, Laos. Land Use Policy, 42, 790-799. Walsh, J., and Southiseng, N. (2009). Vientiane. City. Analysis of urban trends, culture, theory, policy, action. City. Analysis of Urban Trends, Culture, Theory, Policy, Action, 13(1), 95-102. 
Table 1. Demographic trends

\begin{tabular}{|l|l|l|}
\hline & 2005 & 2015 \\
\hline Laos & $5,621,000$ & $6,492,000$ \\
\hline $\begin{array}{l}\text { Luang Prabang } \\
\text { (district) }\end{array}$ & 78,516 & 90,313 \\
\hline $\begin{array}{l}\text { LP urban } \\
\text { districts }\end{array}$ & NA & $66,781(73.9 \%)$ \\
\hline $\begin{array}{l}\text { LP rural districts } \\
\text { puang Prabang } \\
\text { town) (incl. }\end{array}$ & 407,039 & $\begin{array}{l}431,889 \text { (urban } \\
32.3 \%)\end{array}$ \\
\hline $\begin{array}{l}\text { Vientiane } \\
\text { NAnce }\end{array}$ & $\begin{array}{l}820,940 \text { (urban } \\
77.9 \%)\end{array}$ \\
\hline
\end{tabular}

Source: Lao Statistic Bureau (2005, 2015).

Table 1. Census data 


\begin{tabular}{|l|l|l|l|}
\hline & Population & Domestic & International \\
\hline 2015 & 90,400 & 161,712 & 445,872 \\
\hline 2020 & 101,800 & 212,000 & 700,000 \\
\hline 2025 & 114,400 & 293,100 & 800,000 \\
\hline
\end{tabular}

Source: JICA 2016, 2-28.

Table 2. Growing population and tourist flows (2015-2025) 


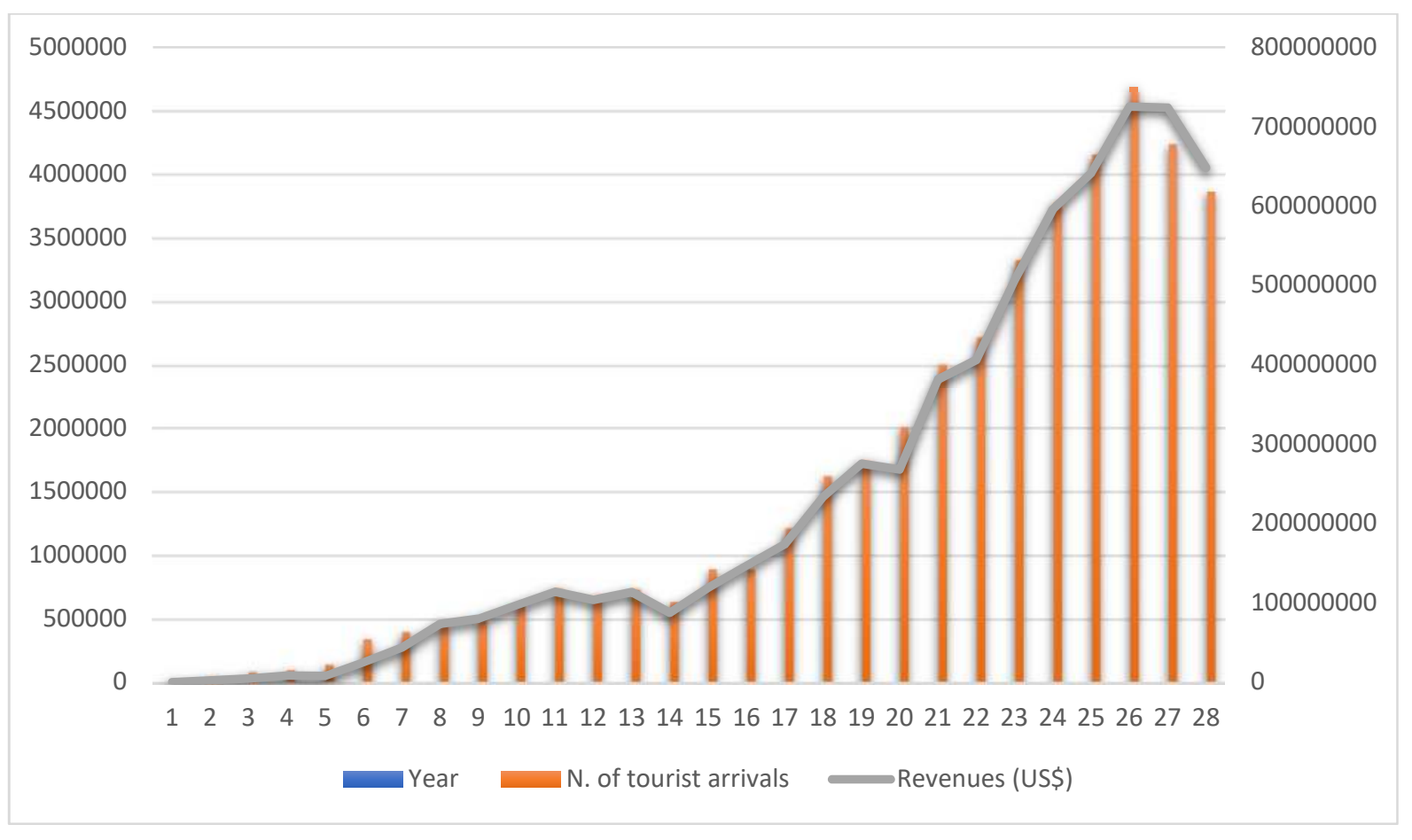

Figure 2. Tourist flows and revenues 


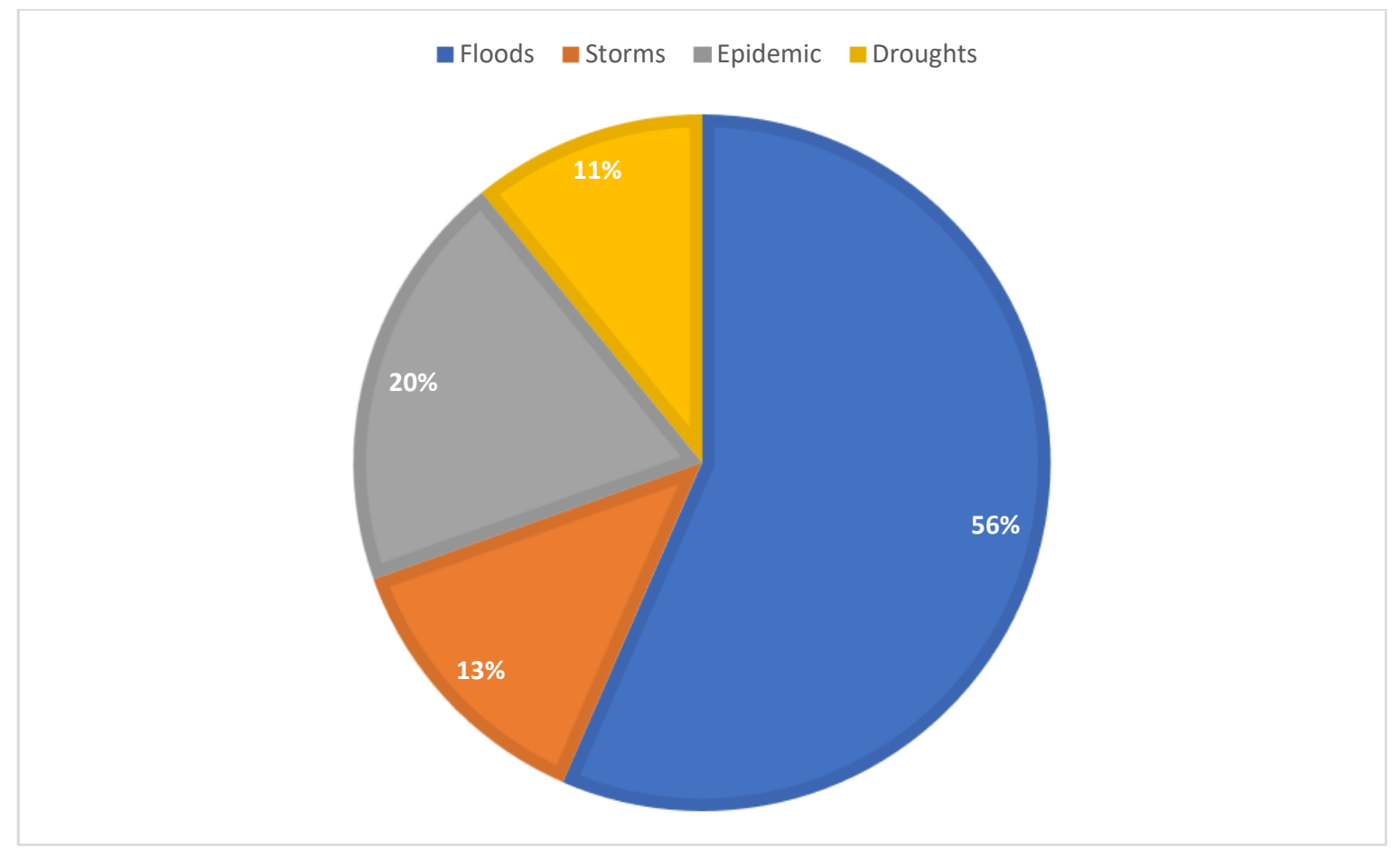

Figure 3. Natural hazards in Laos (1900-2018) 


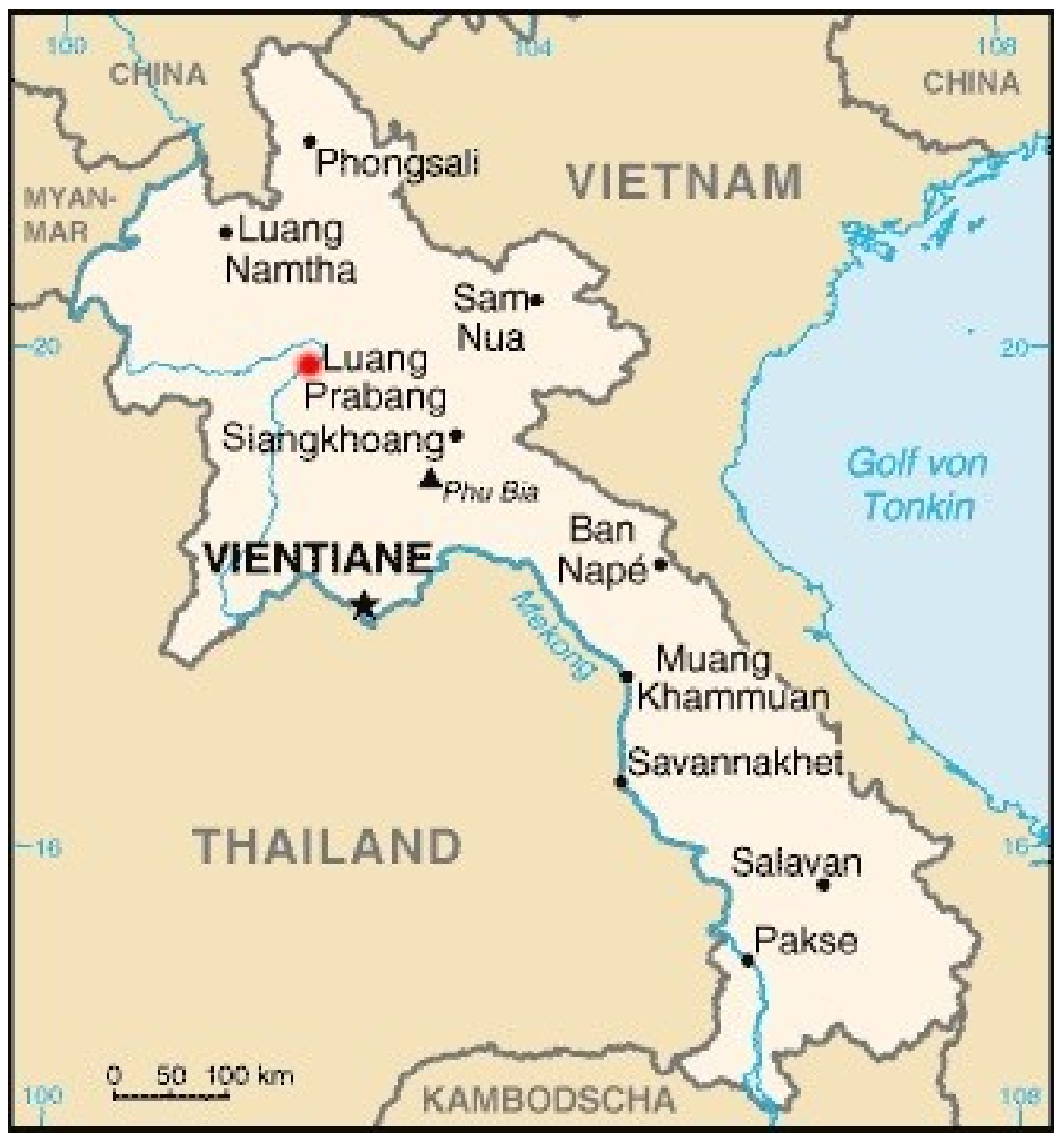

Map 1. Laos 


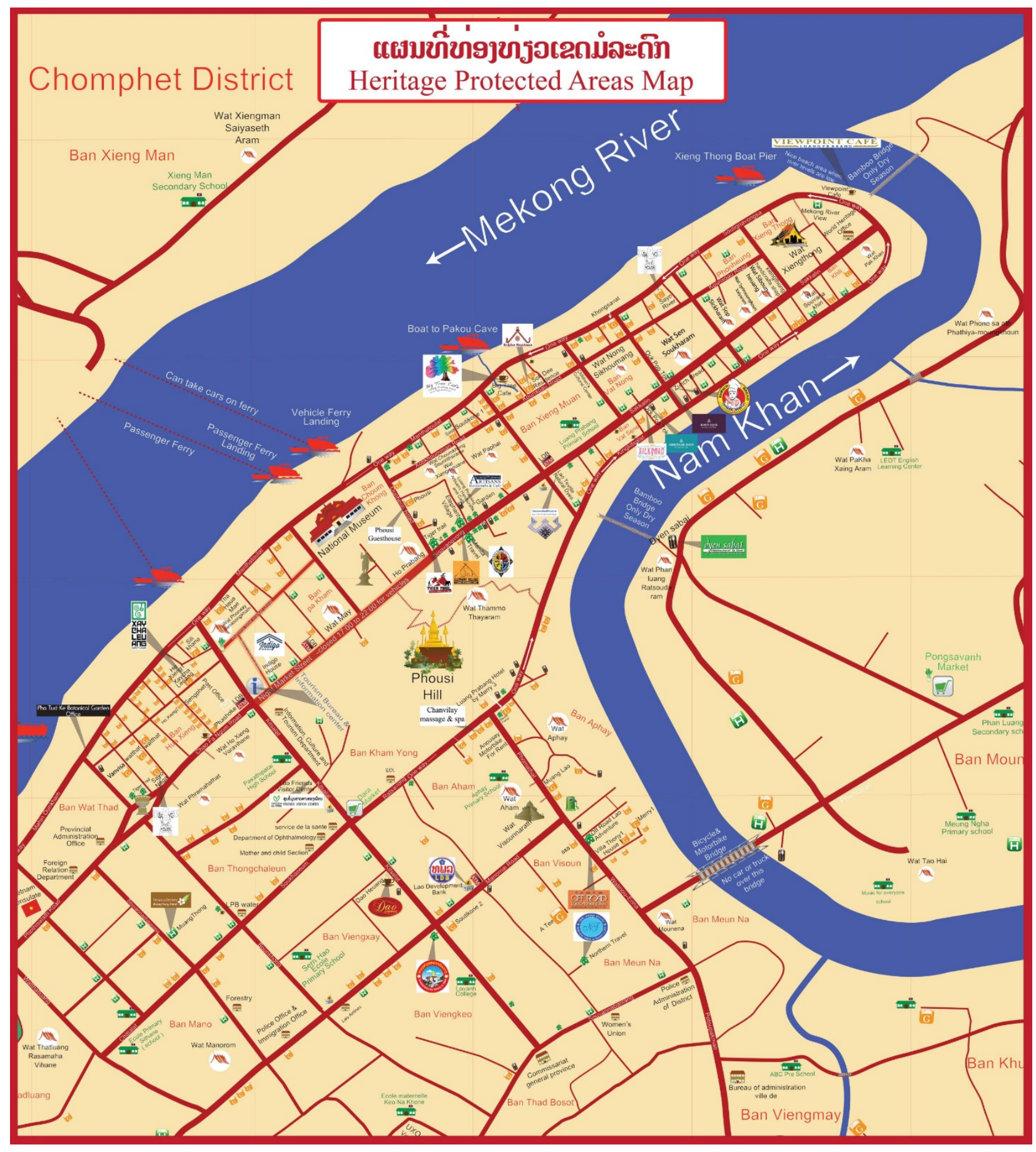

Map 2. Luang Prabang UNESCO World Heritage site 
Luang Prabang Photos and Maps: URL, source, and attribution

Map 1. Laos

Source: Japan International Cooperation Agency. Available at

https://www.jica.go.jp/project/english/laos/006/outline/index.html

Map 2. Luang Prabang Heritage site area

Source: Hobomaps, available at http://hobomaps.com/LuangPrabangAreaMap.html

Photo 1. Aerial view of the rugged terrain behind Luang Prabang

Source: Author's photo.

Photo 2. Wooden bridge on the Nam Khan river

Source: Author's photo.

Photo 3. Colonial buildings in Luang Prabang.

Source: Author's photo.

Photo 4. Wat Xieng Muan

Source: Author's photo.

Photo 5. Night market along Sisavangvong road

Source: Author's photo. 